\title{
Analytical and Statistical Research of State and Households Health Care Expenditures in the Czech Republic
}

\author{
Martina HEDVIČÁKOVÁ ${ }^{1}$, Alena POZDÍLKOVÁ ${ }^{2}$ \\ ${ }^{1}$ University of Hradec Králové, Hradec Králové, Czech Republic \\ Martina.Hedvicakova@uhk.cz \\ ${ }^{2}$ University of Pardubice, Pardubice, Czech Republic \\ alena.pozdilkova@upce.cz
}

\begin{abstract}
The aim of the article is to analyze health care expenditures in the Czech Republic compared to selected countries. Expenditures will be analyzed from the point of view of the state and households. The partial aim of the contribution is a correlation analysis to verify the dependency of household healthcare expenditure and average household income in 2010-2015.

With the rise of modern technology and knowledge, but also with the extension of human life is constantly growing importance of health care. Over the period 2010-2015, total healthcare spending has risen from CZK 340.7 billion in 2010 to CZK 358.0 billion in 2015. Compared with the development of the GDP, total expenditure on health care (including capital) lagged, and their share of GDP fell from $8.6 \%$ to $7.9 \%$ in the years above. Household expenditures on health care in the year 2015 amounted to CZK 49,358 million, or $13.8 \%$ of the total health care expenditures in the Czech Republic. Using Spearman coefficient was shown dependence of health expenditure of households on their income. At the same time, a forecast for healthcare spending was created for 2 years ahead.
\end{abstract}

Keywords: Health Care, Expenditures, Correlation Analysis, Spearman Coefficient, Households.

\section{Introduction}

Human health care is undoubtedly one of the most important socially organized activities. Gradually, with the development of knowledge and the application of its results in practical activities on the one hand and the prolongation of human life on the other, the importance of healthcare is growing. From an economic and social point of view, healthcare requires more and more resources that draw on complex redistribution. Finally, with the development of globalization and the related integration tendencies, the need for sharing information on healthcare and the provision of healthcare internationally will increase. [2] 
Heuvel's and Malaroiu's [6] research shows, that health care expenditures are not the main determinant of life expectancy at birth, but social protection expenditures are. They show that in countries that spend a high percentage of their GDP on social protection, that have fewer curative beds and low infant mortality, whose citizens report fewer unmet health care needs and drink less alcohol, citizens have a significant longer life expectancy. Braendle and Colombier [1] find that per capita income, the unemployment rate and the share of foreigners are positively related to public health care expenditure growth.

Explanations of growth in health expenditures have restricted attention to the mean. Meijer at all. [7] explain change throughout the distribution of expenditures, providing insight into how expenditure growth and its explanation differ along the distribution. Changes in hospital practice styles make the largest contribution of all determinants to increased spending not only on hospital care but also on pharmaceuticals, suggesting important spill over effects.

Income, ageing population and health care technology exert positive effects on U.S. health expenditure per capita. Unlike prior studies, Murthy and Okunade [8] present new empirical evidence indicating that the U.S. health care is a necessity, with an income elasticity estimate of around 0.92 . They find that medical technology advances play a major role in the long run rise of the U.S. health expenditure.

\section{$2 \quad$ Methodology and objectives}

The article is based on primary and secondary sources. Secondary sources comprise information about expenditures on health care in the Czech Republic and abroad, professional literature, information collected from professional press, discussions or previous participations in professional seminars and conferences relating to the chosen subject. Primary sources are based on the information gained from Czech statistical office, OECD, Eurostat, WHO etc. Then it was necessary to select, classify and update accessible relevant information from the numerous published materials that would provide the basic knowledge of the selected topic.

Correlation analysis will be performed (correlation matrix will be composed) in the second part. A Spearman correlation coefficient is an important characteristic in evaluating the validity of tests, because it determines how close together two related phenomena are captured. Thus, it allows quantitative determination of how far the two similar order are created. For the calculation, it is necessary to have a table in which you can specify individual correlated pairs, which are compared to the individual components of the correlation, overall index and the basic form of vector analysis. The result is a dimensionless number, which indicates the degree of correlation between individual freedom and the steam created for each pair of correlation. [4], [5]

The goal of the paper is to focus total expenditures on health care in the Czech Republic. The partial goal is to use correlation analysis to verify the dependence of health spending among households and average household income between 2010 and 2016. 


\section{Expenditures on Health Care in the Czech Republic and selected countries}

In accordance with the SHA Methodology Manual, medical expenses are related to healthcare expenditures for our citizens in the Czech Republic. Expenditure on health care can be broken down into current (operating) and capital (investment).

Over the period 2010-2015, total healthcare spending has risen from CZK 340.7 billion in 2010 to CZK 358.0 billion in 2015 .

Current expenditure on health care increased from CZK 334.1 billion in 2010 to CZK 352.3 billion in 2015 , i.e. by $5.4 \%$ (an average of $0.9 \%$ per year). The dynamics of population development in the Czech Republic was lower compared to this rate (the increase in the average state of the population was $0.1 \%$ ), so the average current expenditure on healthcare per capita increased from $31,768 \mathrm{CZK}$ to $33,960 \mathrm{CZK}$ in 2010-2015 (i.e. 6.9\%).

Total capital expenditures financed directly from state or local health care budgets declined from CZK 6.6 billion in 2010 to 2015 to CZK 5.7 billion (15.8\%).

Compared with the development of the main macroeconomic performance indicator - GDP, total expenditure on health care (including capital) lagged behind, and their share of GDP fell from $8.6 \%$ to $7.9 \%$ in the years above, see Fig. 1. [2]

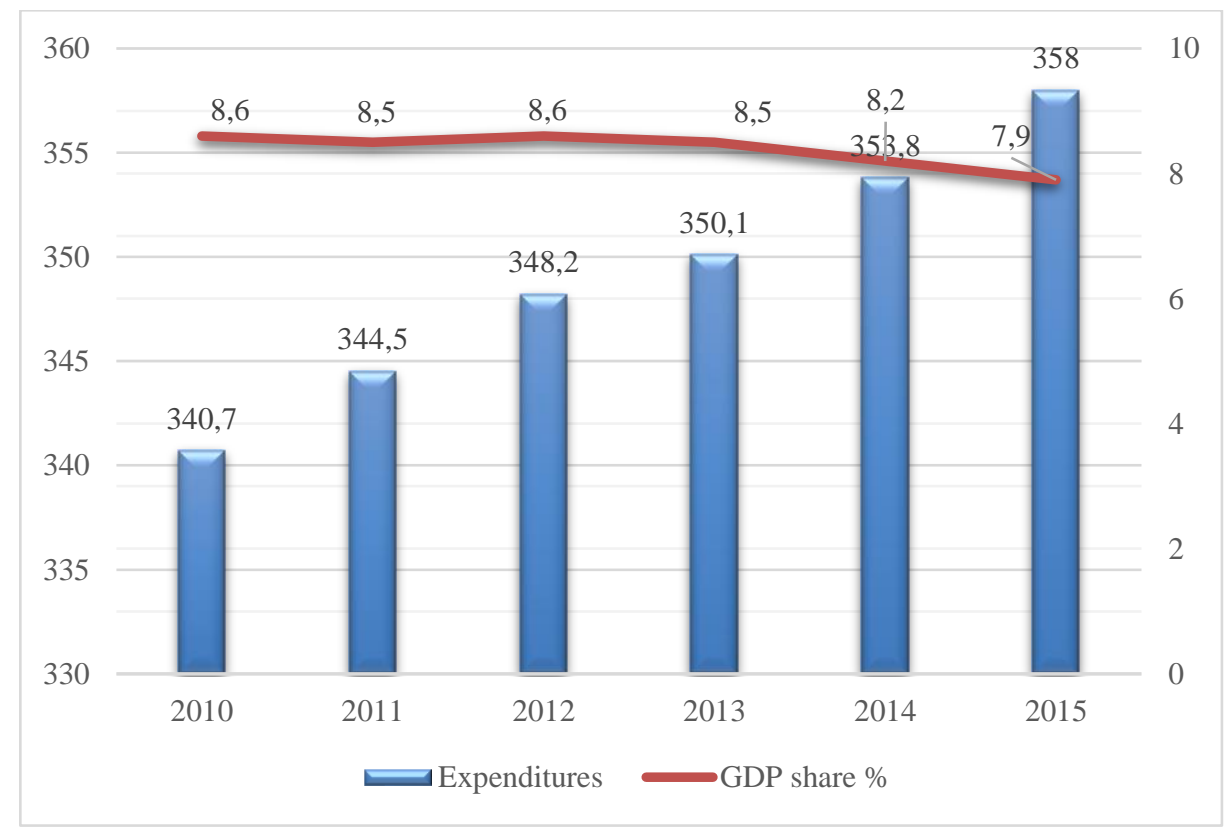

Fig. 1. The development of total health care expenditures in the Czech Republic and its share of GDP, 2010 - 2015 (billion CZK, \%) [2]. 


\subsection{Household expenditure on health care}

Household expenditure on health care in the year 2015 amounted to CZK 49,358 million, or $13.8 \%$ of the total health care expenditures in the Czech Republic. This share ranged between $12.5 \%$ between 2010 and 2013 and exceeded $13 \%$ in 2013. This amount represents more than $2 \%$ of total household expenditure. Since 2010, household spending on healthcare has been above CZK 40 billion, and in the year 2015 it has reached a maximum of CZK 49,358 million. If we were to direct household spending on healthcare per capita, we would have reached 4,600 CZK in 2015 against 4,100 CZK in 2010 (see Fig. 2). [2]

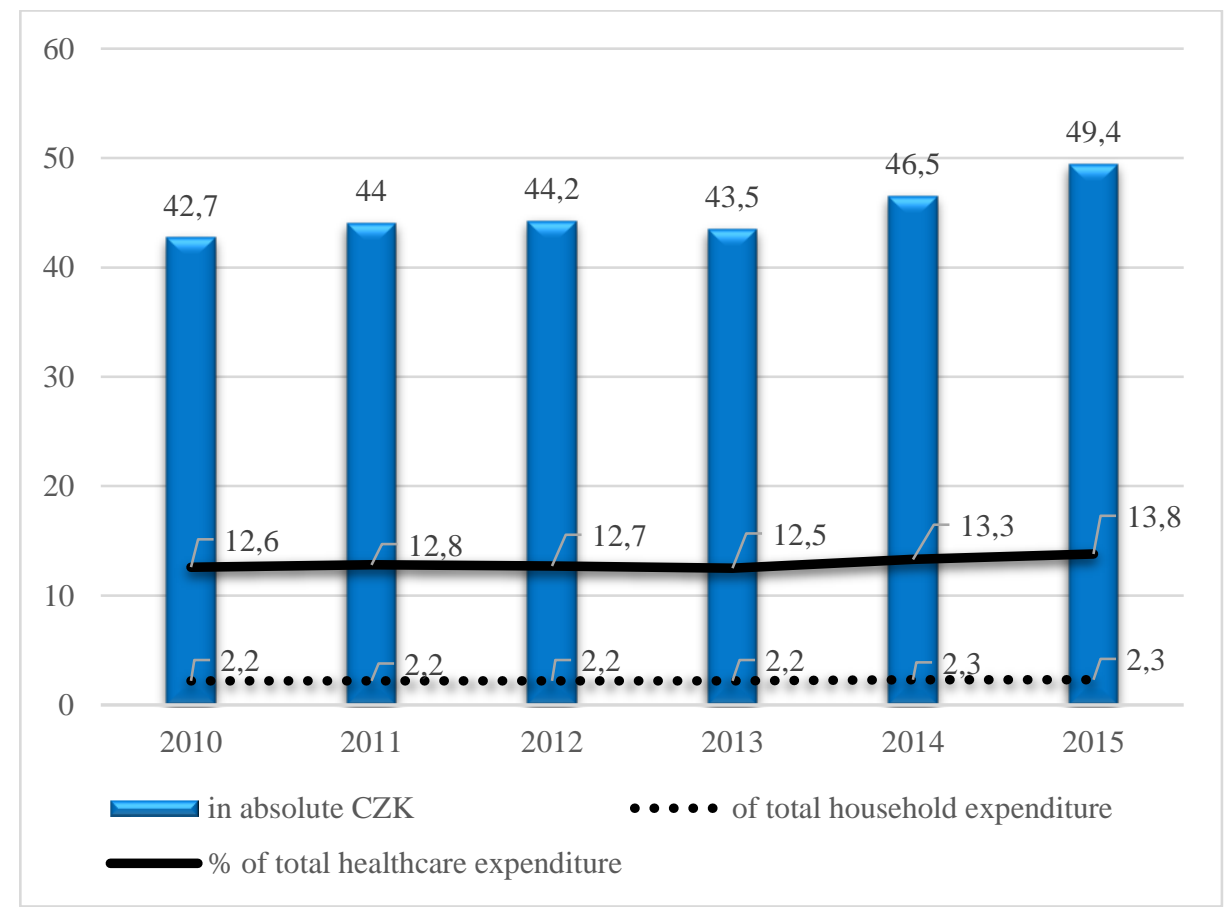

Fig. 2. Direct expenditures of households in the Czech Republic on health care, 2010-2015 (CZK billions; \%) [2].

\subsection{Health spending in selected country}

Health spending measures the final consumption of health care goods and services (i.e. current health expenditure) including personal health care (curative care, rehabilitative care, long-term care, ancillary services and medical goods) and collective services (prevention and public health services as well as health administration), but excluding spending on investments. Health care is financed through a mix of financing arrangements including government spending and 
compulsory health insurance ("Government/compulsory") as well as voluntary health insurance and private funds such as households' out-of-pocket payments, NGOs and private corporations ("Voluntary"). This indicator is presented as a total and by type of financing ("Government/compulsory", "Voluntary", "Out-of-pocket") and is measured as a share of GDP, as a share of total health spending and in USD per capita (using economy-wide PPPs). [10]

Spending on health in the OECD was about USD 4,000 per person on average (adjusted for purchasing powers). The United States spends almost USD 10,000 per person. Health spending was 9\% of GDP on average in the OECD, ranging from 4.3\% in Turkey to $17.2 \%$ in the United States. In all countries except the United States, government schemes and compulsory health insurance are the main health care financing arrangements. Hospitals account for nearly $40 \%$ of health spending. Population ageing has increased the demand for long-term care, with spending increasing more than for any other type of health care. [9]

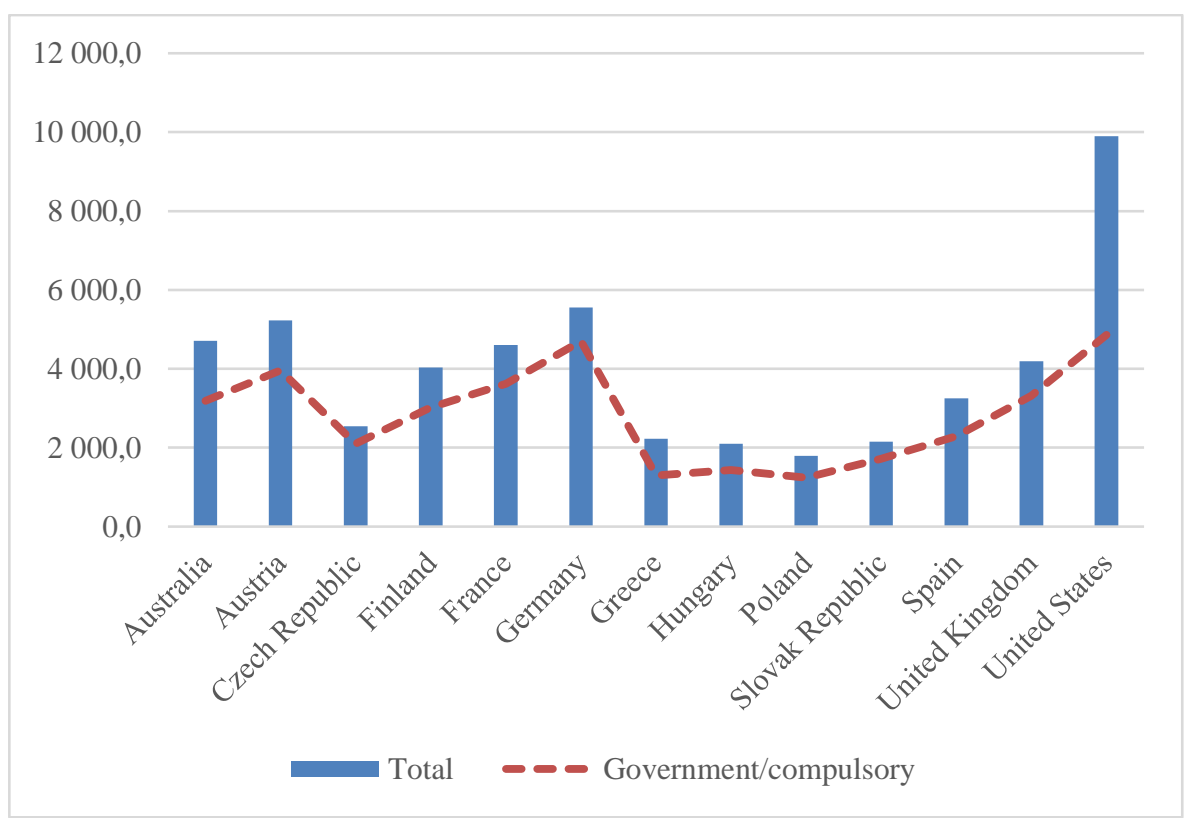

Fig. 3. Health spending in 2016 (US dollars/capita) [10].

According to OECD, the largest amount of funding was spent by United States (17.2\% GDP), Switzerland, Luxembourg, Norway and Germany in 2016. The Czech Republic has earmarked total 2,544 US dollars/capita which is 7.3\% of GDP and government/compulsory was 2,097 US dollars/capita which is 6\% of GDP. Voluntary was only 455 US dollars per capita, which is $1.3 \%$ of GDP. Voluntary is one of the lowest of all the countries compared. The lowest spending on healthcare was reported in Mexico Turkey (total 4.3\% GDP), Latvia and Poland. [10] 


\section{Correlation analysis}

Correlation analysis is based on data from the Czech Statistical between 2010 and 2015. The health care expenditures in individual households are available for the years 2010-2015, so it was necessary to create a linear model based on a forecast for the years 2016 and 2017.

Table 1. Expenditures on Health Care in the Czech Republic [1].

\begin{tabular}{lll}
\hline Year & Expenditures & Prognosis (Expenditures) \\
\hline 2010 & 42.7 & \\
2011 & 44.0 & \\
2012 & 44.2 & \\
2013 & 43.5 & \\
2014 & 46.5 & \\
2015 & 45.0 & 45.00000000 \\
2016 & & 45.65044738 \\
2017 & & 46.14247425 \\
\hline
\end{tabular}

According to forecasts, expenditures on health care should grow over the next two years (see to Tab. 1 and Fig. 4).

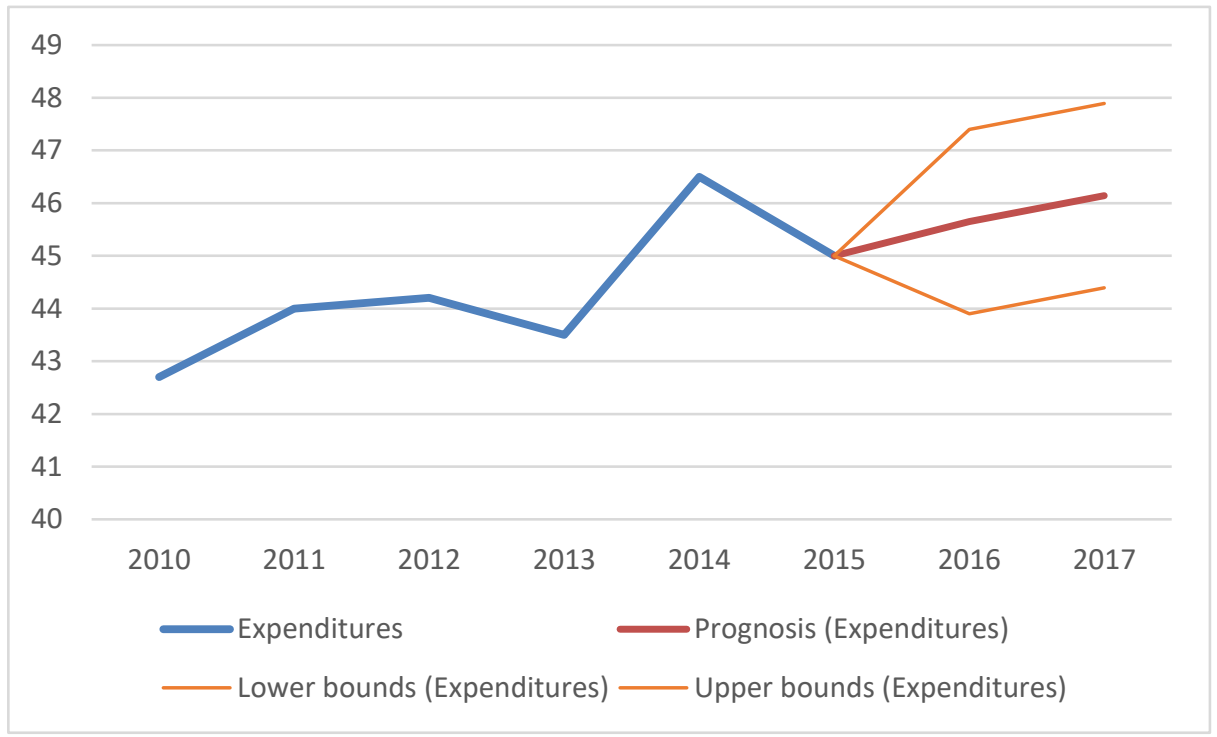

Fig. 4. Expenditures on Health Care in the Czech Republic $[2,3]$. 
Followed by correlation analysis will be verified addiction health expenditure of individual households and average household income between 2010 and 2016.

Spearman coefficient between direct medical expenditures of individual households in the Czech Republic and the average wage, which reflects the average income of the household, came 0.7089 , indicating a correlation between these two variables.

As households' average household income grew, households' total healthcare expenditures increased proportionally, and the households' healthcare expenditure was reliant on their income.

\section{Conclusion and discussion}

Health care expenditures are current in all countries around the world. Governments are trying to optimize the amount of expenditure on health care with regard to economic and social aspects. Health care expenditures in the examined period 2010 2015 to grow in the Czech Republic. Over the whole period under review, however, the share of GDP is decreasing. Household expenditure on health care have increased in the last two years.

Using Spearman coefficient was shown dependence of health expenditure of households on their income. At the same time, a forecast for healthcare spending was created for 2 years ahead. According to the forecast, health care expenditures will rise in the coming years. The question in the discussion is which variables are most involved in rising health care expenditures. Another issue is the role of new modern technologies in healthcare and their impact on expenditures.

Acknowledgements. The paper is supported by the project GAČR 2017 No. 15330/16/AGR Investment evaluation of medical device development run at the Faculty of Informatics and Management of the University of Hradec Kralove, Czech Republic.

\section{References}

1. Braendle, T., Colombier, C.: What drives public health care expenditure growth? Evidence from Swiss cantons, 1970-2012. Health Policy 120(9), 1051-1060 (2016), DOI: 10.1016/j.healthpol.2016.07.009.

2. Czech Statistical Office: Výsledky zdravotnických účtů ČR - 2010-2015 (Revize), https://www.czso.cz/csu/czso/vysledky-zdravotnickych-uctu-cr-2010-2015-

revize?p_p_id=LanguageSelectPortlet_WAR_rsprezentace_INSTANCE_ABCD\&p_p_life lifec $=0 \&$ p_p_state $=$ normal\&p_p_mode $=$ view, last accessed 2017/011/26.

3. Czech Statistical Office: Wages - time series, https://www.czso.cz/csu/czso/pmz_ts, last accessed 2017/011/24.

4. Hedvičáková, M., Pozdílková, A.: Development of Mortgage Loans with Using of Regression Analysis. Advances Science Letters 2015, American Scientific Publishers, 2015. 
5. Hedvicakova, M., Pozdilkova, A., Stranska, P. K., Svobodova, L. Analysis of Mobile Social Networks Using Clustering, Adv. Sci. Lett., 22(5)(2016) 1273-1277.

6. Heuvel, W. J. A., Olaroiu, M.: How Important Are Health Care Expenditures for Life Expectancy? A Comparative, European Analysis. Journal of the American Medical Directors Association 18(3), 276.e9-276.e12 (2017).

7. Meijer, C., O’Donnell, M. O., Koopmanschap, M., Dorslaer, E.: Health expenditure growth: Looking beyond the average through decomposition of the full distribution. Journal of Health Economics 32(1), 88-105 (2013), DOI: 10.1016/j.jhealeco.2012.10.009.

8. Murthy, V. N. R., Okunade, A. A.: Determinants of U.S. health expenditure: Evidence from autoregressive distributed lag (ARDL) approach to cointegration. Economic Modelling 59(December 2016), 67-73 (2016), DOI: 10.1016/j.econmod.2016.07.001.

9. OECD: Health at a Glance 2017: OECD Indicators. 1st edn. OECD Publishing, Paris (2017).

10. OECD: Health spending, http://www.oecd-ilibrary.org/social-issues-migrationhealth/health-spending/indicator/english_8643de7e-en, last accessed 2017/12/16. 